\title{
Jobs and kids: female employment and fertility in China
}

\author{
Hai Fang ${ }^{1 *}$, Karen N Eggleston², John A Rizzo ${ }^{3}$ and Richard J Zeckhauser ${ }^{4}$
}

\author{
* Correspondence: \\ hfang@hsc.pku.edu.cn \\ ${ }^{1}$ China Center for Health \\ Development Studies, Health \\ Science Center, Peking University, \\ No.38 Xueyuan Road, Haidian \\ District, P.O. Box 505, Beijing \\ 100191, China \\ Full list of author information is \\ available at the end of the article
}

\begin{abstract}
Data on 2,355 married women from the 2006 China Health and Nutrition Survey are used to study how female employment affects fertility in China. China has deep concerns with both population size and female employment, so the relationship between the two should be better understood. Causality flows in both directions; hence, we use a plausible instrumental variable to isolate the effect of employment on fertility. Female employment reduces a married woman's preferred number of children by 0.35 on average and her actual number by 0.50. Ramifications for China's one-child policy are discussed.

JEL codes: J13; J18; 015

Keywords: Fertility; Female labor supply; Employment in China; Employment and fertility; One-child policy
\end{abstract}

\section{Introduction}

Seminal contributions to the economic theory of the household show that fertility and job market behavior are interrelated choices, since both strongly affect household time allocation (Becker 1960, 1965; Mincer 1962; and Willis 1973). The global fall in fertility and increase in female labor-force participation over the past century might plausibly represent a single causal process of demographic transition, as posited by Soares and Falcao $(2008)^{1}$. These two sets of theories support a link between female labor force participation and fertility decisions, with causality flowing in both directions. Several empirical studies confirm these predictions (see for example, Killingsworth and Heckman 1986; Angrist and Evans 1998; Kalwij 2000; and Lehr 2009). Better labor-force opportunities for women appear to have played a role in the historic reductions in fertility that defined the demographic transition that swept Europe and the United States from the $1800 \mathrm{~s}$ to the early 20th century (Guinnane 2011). By increasing the opportunity costs of childbearing, locally available industrial employment opportunities (such as the opening of a nearby textile factory) reduced marital fertility by small but significant amounts (Schultz 1985; Crafts 1989; Brown and Guinnane 2002). The study of such transitions in developing countries remains limited, however.

China is a particularly important place to study the relationship between women's employment and fertility, given its rapid pace of economic development, enormous population, and controversial family planning policies. With more than 1.3 billion people in 2010, China is the most populous nation in the world (Peng 2011). For the

\section{Springer}

(C) 2013 Fang et al.; licensee Springer. This is an open access article distributed under the terms of the Creative Commons Attribution License (http://creativecommons.org/licenses/by/2.0), which permits unrestricted use, distribution, and reproduction in any medium, provided the original work is properly cited. 
past 40 years, China has sought to control population growth. The "one-child" policy, initiated in 1979, limits most urban couples to precisely that, and constrains most rural couples to no more than two children, or one son (Peng 2011). Although fertility rates had already begun to decline steeply before this policy was introduced, the one-child policy appears to have substantially reduced fertility rates and population growth (Banister 1987; Wang 2011; and Peng 2011) ${ }^{2}$.

Our analysis uses 2006 data from the China Health and Nutrition Survey to assess how female employment affects fertility in China. A major challenge in inferring the effect of female employment on fertility is the reverse causal flow, noted above. To overcome this endogeneity problem, we employ an instrumental variable that facilitates access to employment opportunities - the availability of a bus stop in the residence community - to estimate female employment status. To the best of our knowledge, this is the first study to analyze the causal effects of female employment on fertility behavior using data from China ${ }^{3}$.

We study fertility preferences and actual fertility, and find that off-farm employment significantly reduces both. Controlling for endogeneity increases the estimated effect of female employment status on fertility. Our preferred specification indicates that female employment reduces the preferred number of children by 0.35 on average, and the actual number of children by 0.50 . Having a first child who is a son is associated with lower fertility, both preferred and actual.

The rest of the paper is organized as follows. Section 2 provides background information about China's population control policy, and Section 3 presents a simple conceptual framework. Data and variables are described in Section 4. Section 5 presents our estimation strategy, and Section 6 shows the results. Section 7 summarizes our findings and discusses their policy implications.

\section{China's population control policies}

Due to its huge population, China has employed various population control policies for the past 40 years. In 1971, when the population was more than 800 million, China integrated population control into its national economic development plan. In 1973, the central government started the "Later, Longer, and Fewer" family-planning campaign to encourage later marriage, longer intervals between births, and fewer children. In 1978, China encouraged couples to have only one child, and set the maximum at two. It also added family planning to its constitution. The next year China's State Council began implementing the so called "one-child policy" through the family planning administration, emphasizing population control as a strategic requirement for China's development.

Although China's policy is called the one-child policy, many couples are allowed to have more than a single child (Peng 2011). Most ethnic minorities (that is, non-Han ethnic Chinese) are permitted to have more than one child. In rural areas, a couple may usually have a second child if the first child is a girl or is disabled. To implement the restrictions on childbearing, local governments provide financial subsidies to families with one child, and impose substantial penalties if a couple violates the population control policies by having an "out of quota" birth"

There are several reasons why enforcement of a strict one-child policy has been difficult in China. Children - especially sons - are valued for contributing to farm labor 
(Schultz and Zeng 1995) and for providing parents with old-age security (Hussain 1994), since social security and pension systems in China are both recent and limited. The one-child policy is also often linked to the increase in China's unbalanced sex ratio, enabled by ultrasound technology that permits sex-selective abortion ${ }^{5}$. Our study focuses on how female employment affects fertility in China. If employment reduces fertility, encouraging female employment could be an alternative tool for limiting population growth in China.

\section{Conceptual framework}

Consider a simple model of a woman with opportunities for off-farm employment. How do those opportunities affect the number of children she desires? We posit a utility function for a united household - woman and husband - but for ease of exposition, speak of the woman as the decision-maker. She values consumption, c, leisure, $d$, and children. Her utility function is

$$
U(c, d, n)=u(c)+v(d)+n w(n),
$$

where $n$ is the number of children. There are diminishing returns to each argument. To simplify, we assume that household income apart from her earnings are $Y$, and that off-farm employment requires a time commitment of $K$ hours per week, and that care of each child requires $h$ hours per week. All income goes into consumption, and any time not spent raising children or working (and commuting to work) goes into leisure.

Women differ along two dimensions: preference for children, and opportunities for off-farm employment. Utility from children is non-linear: $w(n)=b a^{n-1}$, with $0<a<1$ common to all women. To capture differences in fertility preferences, we assume a distribution of the "taste for children" parameter, $b$. Differences in off-farm employment opportunities is represented by the distribution of the off-farm employment salary, $s$.

Three facts should be evident: 1 . women offered a higher salary are more likely to accept employment; 2 . women with a greater taste for children will desire more children and will require a higher wage before they work; and 3. among women with the same taste for children, women who are employed, having less time to allocate, will prefer fewer children ${ }^{6}$.

Let $I_{w}$ be the indicator for whether a woman chooses to work off the farm. The women's optimization problem is

$$
\max _{c, d, n, I_{W}} U(c, d, n) \text { s.t. } I_{W}(K-t)+n h+d \leq 168 \text { and } c \leq Y+I_{W}(s),
$$

where $t=0$ with no bus stop and $t>0$ with a bus stop (i.e., access to a bus stop saves travel time to employment and thus reduces the time commitment of an off-farm job).

For our simulation, we assume $u(c)=\ln (c)$ and $v(d)=\ln (d)$. Solving for $c$ and $d$ and substituting, we find that a woman's optimization problem becomes

$$
\max _{n, I_{W}} \ln \left(Y+I_{W}(s)\right)+\ln \left(168-I_{W}(K-t)-n h\right)+n b a^{n-1} .
$$

The distribution of taste for children and opportunities for employment will determine how many women choose employment and how many children employed and unemployed women will prefer. The parameters in our simulation of the model (results shown in Figure 1) are as follows: $\mathrm{Y}=50, \mathrm{~K}=60, \mathrm{a}=0.7, \mathrm{~h}=20 ; s$ ranges 


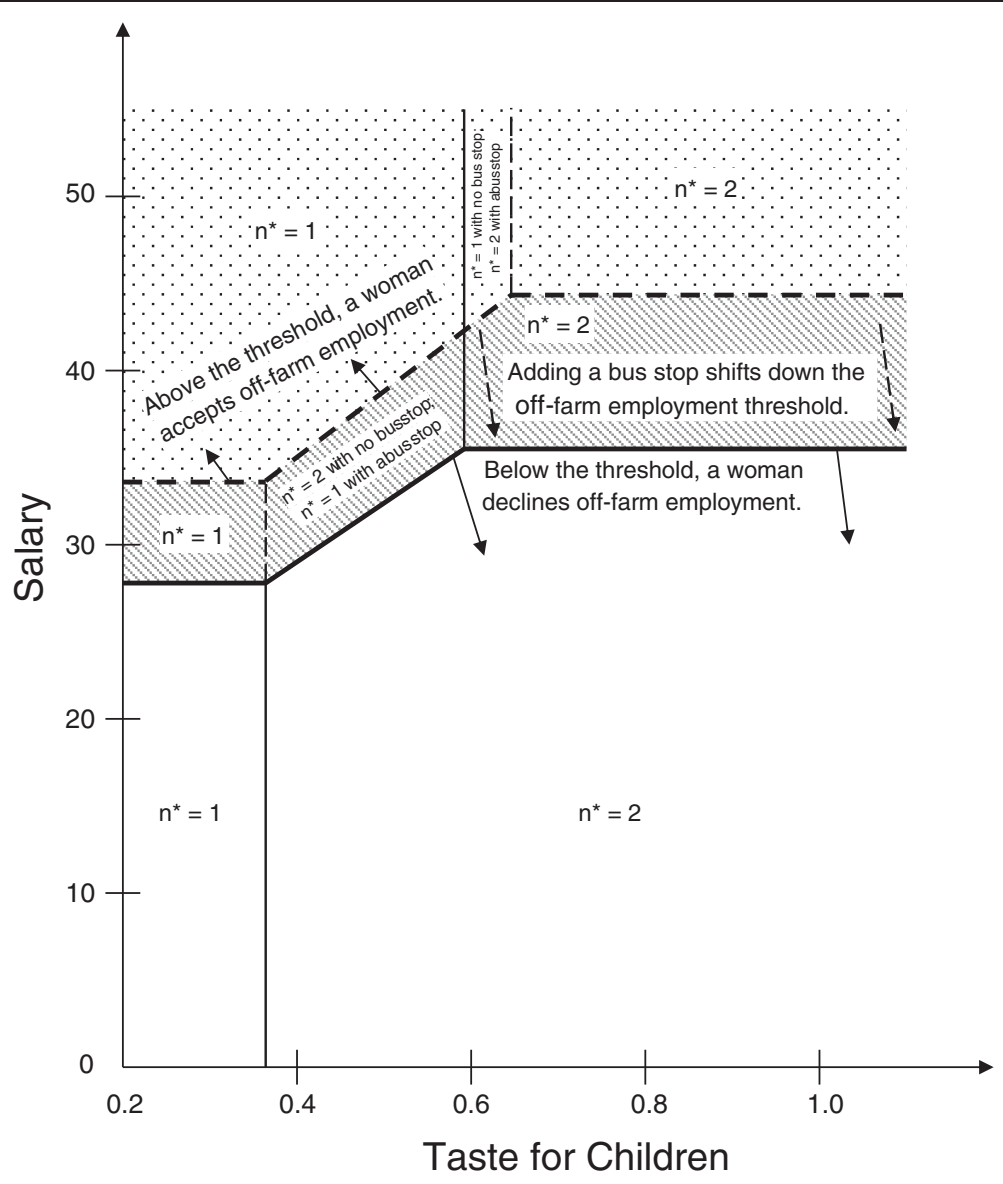

Figure 1 Simulation model of preferred number of children.

between 0 and 55; and $b$ ranges between 0.2 and 1.1. The values of $s$ and $b$ are such that they form a uniform sampling distribution between the limits given. These parameter values were selected with two considerations: simplicity and their ability to approximate actual fertility results. Drawing on our empirical data, we assume that 815 women reside in communities with no bus stop $(t=0)$, and 1540 have access to a bus stop $(t=7)$.

Figure 1 shows the number of children a woman will want as a function of the offered salary and her taste for children. The figure shows cut-off ranges for the preferred number of children in whole numbers (i.e., one or two children). For any given $b$ (the preference parameter for children), there is a minimum salary offer above which a woman will accept off-farm employment. Having access to a bus stop shifts down the off-farm employment threshold, as shown in the shaded area of Figure 1. For women in the intermediate range of taste for children, there is an upward-sloping threshold for employment, indicating that they must be offered a higher salary to accept employment (to compensate for the opportunity cost of lost time to care for children). When these women have access to a bus stop, they change from $n^{*}=2$ to $n^{*}=1$ : employment reduces preferred fertility. Those with the highest taste for children prefer to have more than one child, whether or not they work. 
Overall, in our simulation portrayed in Figure 1,35\% of women choose employment off the farm. The preferred number of children among those who choose employment (1.46) is significantly less than among those who do not (1.84). As surmised, access to a bus stop increases the percentage of women who choose employment off the farm (from $26 \%$ in non-bus-stop communities to $40 \%$ for bus stop communities). In other words, where salary opportunities are poor, only $26 \%$ of women accept off-farm employment, but in communities with good salary opportunities, $40 \%$ accept employment. The presence of a bus stop, by lowering travel time to higher-salary jobs, encourages more women to seek off-farm employment. Those who are employed include women from the higher tail of the child-preference distribution, and therefore the average number of preferred children among working mothers is higher in the bus stop communities (1.50) than it is in non-bus-stop communities (1.36) ${ }^{7}$.

This model is consistent with what we find in our empirical work below: where opportunities for better-paid off-farm employment are greater, significantly more women accept employment; and regardless of location, employed women prefer fewer children (and are more likely to prefer only one child), compared to women who do not work off the farm.

\section{Data and variables}

\subsection{Data}

We utilize 2006 data from the China Health and Nutrition Survey (CHNS), which is maintained at the Carolina Population Center of the University of North Carolina at Chapel Hill. The CHNS is an ongoing international collaborative project by the Carolina Population Center and the National Institute of Nutrition and Food Safety at the Chinese Center for Disease Control and Prevention. The CHNS was developed to promote the study of social and economic changes in Chinese society on health and nutrition. It was fielded by an international team of researchers whose backgrounds include nutrition, public health, economics, sociology, Chinese studies, and demography. Our study uses the 2006 wave of data, including 11,739 respondents.

Mainland China consists of 32 province-level administrative units. The CHNS data were collected from 9 provinces which account for 44 percent of the Chinese population in 2007: Heilongjiang, Liaoning, Jiangsu, Shandong, Henan, Hubei, Hunan, Guangxi, and Guizhou. These 9 provinces vary substantially in geography, economic development, public resources, and health indicators, with greater wealth and development in the east. Heilongjiang and Liaoning are two heavily-industrialized provinces in northeastern China. Jiangsu and Shandong are two industrialized provinces in eastern China. Henan, Hubei, and Hunan are three agricultural provinces in central China, and Guangxi and Guizhou are relatively underdeveloped southwestern provinces.

The CHNS employed sophisticated sampling techniques. A multistage, random cluster process was used to draw the sample surveyed in each of the provinces. Counties in the 9 provinces were stratified by income (low, middle, and high) and a weighted sampling approach was used to randomly select 4 counties within each province. In addition, the provincial capital and a lower income city were selected when feasible. Villages within the counties, and urban and suburban neighborhoods within the cities, were selected at random. The CHNS has a community survey that accompanies each 
wave, which collects information from community officials and business venders. Communities are defined as rural villages and urban neighborhoods.

Because our study focuses on the fertility preferences of married women in China and also uses actual fertility as a robustness check, only respondents who are married, widowed, or divorced, and under age 52 in 2006 are included, resulting in a sample of 2,355 adult female respondents. The CHNS fertility preference questionnaire is not asked of women who were never married, or who are 52 years old or older. Since the official retirement age for women in China is 55, having to confine our sample to women less than 52 years of age nevertheless allows us to analyze virtually all women with the potential to be in the formal labor force.

\subsection{Variables}

Two fertility variables are employed. The first measures fertility preference as the number of children that a woman says she would prefer to have. The second variable measures actual fertility as the number of surviving children of an ever-married female ${ }^{8}$. Both fertility variables are count measures. To obtain information on fertility preferences, the CHNS questionnaire asked "if you could choose the number of children to have, how many more children would you want to have?" Thus, the preferred number equals the actual number of children plus the number of additional children that a woman would like to have. While it is conceivable that some women may prefer fewer children than they currently have, we believe that the effect of this on fertility is extremely low in China for several reasons. Ample evidence suggests that Chinese women have low-cost access to fertility control, so would not give birth to more children than they prefer"; challenges in implementing the one-child policy reveal that it suppresses fertility below the preferred level; children remain highly valued for old-age support, especially in rural areas; and couples without children are often discriminated against in China, because people believe that they have a physical disability (infertility). Given the valuable economic role of children (especially sons, but increasingly daughters as well ${ }^{10}$ ), and the fertility constraints imposed by the state, most women would prefer at least as many children as they have ${ }^{11}$.

This study uses a binary variable indicating whether the respondent has a job off the farm to measure female employment status. Each respondent is asked "are you presently working?" If the answer is yes, the respondent is further asked "what is your primary occupation?" The employment variable equals 1 if a woman is presently working and her primary occupation is not farmer, fisherman, or hunter; and equals 0 otherwise. Almost all the rural households have farming lands assigned by the local government, so they can potentially work on their land if they do not have off-farm jobs. Working as a farmer, fisherman, or hunter (the majority are farmers) still provides considerable time and flexibility for women to combine childcare with work, so we include these occupations in the sample not employed off the farm. Employment in this paper is thus defined as off-farm employment. Our hypothesis is that the cost of having more children is higher for women employed off the farm than for those not so employed.

All the employed females in our sample have formal employment, and their occupations fall into the following categories: senior professional/technical worker (doctor, professor, lawyer, architect, engineer), junior professional/technical worker (midwife, nurse, teacher, 
editor, photographer), administrator/executive/manager (proprietor, government official, section chief, department or bureau director, administrative cadre, village leader), administrative staff (secretary, office helper), skilled worker (foreman, group leader, craftsman), non-skilled worker (ordinary laborer, logger), army officer, police officer, ordinary soldier, policeman, driver, athlete, actor, musician, and service worker (housekeeper, cook, waiter, doorkeeper, hairdresser, salesperson, launderer, child care worker). Virtually all of these occupations require a formal employment relationship. Thus, informal employment has been excluded from the employed sample. Farmers and other informal employees (such as part-time employees) are treated as part of the non-employed sample.

\subsubsection{Instrumental variables}

In assessing how off-farm employment for women affects fertility in China, a central challenge is that employment is likely to be endogenous for two reasons: unobservable factors and simultaneity (reverse causality) (Wooldridge 2002, pp. 50-51). Factors not observable to researchers or omitted in the estimation, such as employment opportunities, the cost of raising a child, and the income effects of employment, are correlated with female employment status and may also affect fertility. The number of children a woman has, and intends to have, also affects her ability and desire to work, as our conceptual framework shows. Such reverse causality produces a simultaneity problem. Indeed, the number of children has long been recognized in the labor economics literature as an important factor affecting female labor supply (Killingworth and Heckman 1986; Angrist and Evans 1998).

We apply an instrumental variable (IV) approach to help control for these endogeneity concerns. To be effective, our IV must be correlated with the endogenous variable - offfarm employment - but should not directly affect fertility after controlling for a woman's employment status. Our instrumental variable is whether there is a bus stop in the village or urban neighborhood where the woman resides. A bus stop will enable women to work in other villages or towns, thereby boosting their job opportunities. Bus stops are particularly important in China, since transportation options are limited and poor people must rely upon public transportation. Data for this instrumental variable are taken from the CHNS 2006 Community Survey (supplement to the CHNS 2006), and are reported by the community (village/neighborhood) heads or cadres instead of the household survey respondents.

Our conceptual model shows one way in which access to a bus stop could potentially affect fertility directly, by saving time in commuting to work for women who would prefer to have more children. We believe that bus stops may potentially affect fertility choices even if we control for employment, but the effect should be small. In our sample, preferred fertility is very close for employed women with and without bus stops. Empirically, when we run the two stage least squares estimation (reported below), the first stage results show that bus stops can be excluded (by the exclusion test) once we control for employment status.

A review of policy documents suggests that the set-up of bus stops is largely determined by government administrative needs, population size, and road infrastructure. Bus stops have proliferated more quickly in urban areas, but by 2006 they had also developed extensively in rural areas. Because good transportation can enhance economic development, 
China has been investing substantial amounts in improving transportation infrastructure down to the village and neighborhood levels.

The administration system in rural China includes county, township, and administrative villages. One county (xian) includes several townships (xiang), and one township includes several administrative villages (xingzheng cun). The administrative village is the lowest administration or government level in China, and may cover several natural villages (ziran cun). An administration village is often the largest natural village among several neighboring natural villages. Policies have subsidized standard roads (gong $l u$ ) to various villages and neighborhoods. Bus stops are usually set up first in counties and townships, and later are extended to each administrative village and large natural villages. Although we cannot completely rule out the possibility that bus stops are set up partly in response to demand for female employment, we think that this is highly unlikely, and we show that in our data bus stops do not affect fertility directly after controlling for female employment status.

The estimated average treatment effect will be biased if the subjects who are influenced by the instruments do not represent the overall population (Imbens and Angrist 1994). This would occur, for example, if the instruments applied to only a small subset of the sample, e.g., a very small percentage of households own a private car. But the IV used in this study affects a wide range of the observations in our study sample, not simply a small subset: 60 percent of unemployed women and 75 percent of employed women in our sample have access to a bus stop in their villages/neighborhoods ${ }^{12}$. This sizable prevalence will ensure that our estimates are close to the true average treatment effect ${ }^{13}$.

Our IV is constructed from data in the 2006 CHNS community survey, the same year as the CHNS survey data for female employment and fertility. Results are very similar when we use bus stop information from the 2000 or 2004 CHNS community survey data ${ }^{14}$.

\subsubsection{Other explanatory variables}

Our multivariate estimates control for other explanatory variables that may affect fertility. Household income has been found to positively affect fertility in China, so we include a measure of total household income ${ }^{15}$. Ethnic minorities in China are often allowed to have more than one child, so we include a binary variable indicating minority status (of the wife and/or husband). Because a strong preference for sons is still apparent in China (e.g., Coale and Banister 1996; Li et al. 2010), we also include a binary variable indicating whether the first child is a son. We expect that women who already have a son as the first child will have or prefer to have fewer children than those who do not.

The socio-demographic factors we adjust for include: age, educational attainment (less than primary school, primary school, lower middle school, upper middle school, technical school, and college), current marital status (married and widowed/divorced), and province of residence. (Heilongiiang serves as the reference province). Including the province where the respondent resides further controls for unobserved environmental or cultural characteristics that may be correlated with female employment and fertility. We also control for smoking and alcohol consumption status. Smoking may lead to infertility (Howe et al. 1985; and Bolumar et al. 1996). Alcohol consumption may indicate an individual's addictive traits and responsibility level, which may influence fertility. Alcohol consumption also often complements smoking. 
Finally, the multivariate estimation also controls for village or neighborhood population density, population control policies implemented in the communities (i.e., whether a couple of Han ethnicity is allowed to have two children if the first child is a girl, and whether a couple receives a subsidy if having only one child), and urban or rural location.

\section{Estimation strategy}

Our fertility measures are

$F_{p}=$ preferred number of children, and

$\mathrm{F}_{\mathrm{a}}=$ actual number of children.

Both measures are estimated using the same empirical model, which assumes that fertility is a function of female employment and other explanatory variables:

$$
\mathrm{F}_{\mathrm{i}}=\beta_{0}+\mathrm{X} \beta_{1}+\mathrm{E} \beta_{2}+\varepsilon
$$

where

$\mathrm{F}_{\mathrm{i}}=$ fertility measure, $\mathrm{i}=\mathrm{p}$ or $\mathrm{a}$;

$\mathrm{X}=\mathrm{a}$ vector of other explanatory variables;

$\mathrm{E}=\mathrm{a}$ binary indicator of whether the woman is employed in an off-farm job;

$\beta_{0}-\beta_{2}=$ coefficients to be estimated; and

$\varepsilon=$ the disturbance term.

The key coefficient of interest is $\beta_{2}$, the effect of female off-farm employment on fertility. The previous literature has employed ordinary least squares (OLS) (Zhang 1990) and count variable estimation (Poisson) (Schultz 1988) to estimate Equation (1). Given that fertility measures are count variables, Poisson estimation seems more appropriate.

As discussed above, we employ instrumental variables to overcome endogeneity bias. A two-stage least squares estimation is implemented. The first-stage regression model is:

$$
\mathrm{E}=\alpha_{0}+\mathrm{X} \alpha_{1}+\mathrm{IV} \alpha_{2}+\mathrm{u}
$$

where

IV = instrumental variable;

$\alpha_{0}-\alpha_{2}=$ coefficients to be estimated; and

$\mathrm{u}=$ the disturbance term.

Equation (2) will be estimated by OLS estimation at the first stage in the two-stage least squares model. Traditional two-stage least squares estimation assumes that both the fertility measures and the employment measure are continuous, but in this context obviously they are not. The fertility measure is a count variable, while our employment measure is binary. Therefore, OLS and two-stage least squares are unlikely to provide efficient estimates of the effect of female employment status on fertility. Thus, after presenting traditional results for ordinary and two-stage least squares, we turn to a Poisson estimation procedure. We do so first without correcting for endogeneity, and then present a two-stage Poisson estimation that corrects for endogeneity.

Unfortunately, it is not feasible to replace the employment status measure with its predicted value from the first stage in the two-stage Poisson model (Terza et al. 2008). Therefore, for our Poisson results we use two-stage residual inclusion estimation (Terza et al. 2008), which is equivalent to control function estimation (Rivers and Vuong 1988; and Smith and Blundell 1986). The first stage of this two-stage residual inclusion estimation is similar to that in Equation (2). That gives us the 
estimated residual instead of the predicted dependent variable. Considering the binary nature of female employment status, our model in the first stage will be a Probit estimation to obtain the generalized residual (Gourieroux et al. 1987). Then we insert this generalized residual from the first stage, namely $\hat{u}$, into Equation (1) as follows:

$$
\mathrm{F}=\beta_{0}+\mathrm{X} \beta_{1}+\mathrm{E} \beta_{2}+\hat{u} \beta_{3}+\varepsilon .
$$

If the coefficient on û proves to be statistically significant, that indicates that female employment status is endogenous (Rivers and Vuong 1988; Smith and Blundell 1986; and Terza et al. 2008) conditional on the validity of our instrumental variable. The endogeneity-corrected coefficient $\beta_{2}$ in Equation (3) provides an unbiased estimate of the effect of female employment status on fertility (Terza et al. 2008). Due to the two-stage feature of this approach, the estimated standard errors in Equation (3) are underestimated (Terza et al. 2008). Thus, we employ bootstrapping techniques with 1,000 replications to obtain the corrected standard errors.

\section{Results}

\subsection{Descriptive statistics}

Our study sample in 2006 includes 2,355 ever-married women between 20 and 52 years old $^{16}$. Table 1 shows descriptive statistics by female employment status. In our sample, 35.71 percent (841 women) are employed in full-time or part-time off-farm jobs. This employment rate is consistent with previous studies ${ }^{17}$. A woman who is not employed would prefer to have 1.768 children on average, while an employed woman would prefer 1.378 children, a difference of 0.380 children. On average, a woman who is not employed has 1.650 children and an employed woman has 1.202 children, a difference of 0.448 children. Thus, when comparing employed and unemployed women, differences in the preferred number of children are close to but smaller than those in the actual number of children ${ }^{18}$.

Among women not employed in off-farm jobs, 60.2 percent have access to a bus stop in their own village or neighborhood; this percent rises to 74.7 for the employed sample. Thus, having a bus stop nearby is positively correlated with female employment status, suggesting that our instrumental variable has potential.

Table 1 also provides descriptive statistics for the other explanatory variables by employment status. Compared to women who work at home, employed women have higher household income, are less likely to be minority, are more likely to have a son as the first child, are less likely to smoke but more likely to drink alcohol, are more likely to have health insurance, have more education, and enjoy better health status. The average age of a woman who works at home is 40.5 , and that of employed women is 39. This slight gap in ages cannot explain the substantial differences in fertility between these two groups.

Table 2 shows the fertility measures by female employment status. Compared to their employed counterparts in both urban and rural areas, women who are not employed off the farm have more children, prefer to have more children, and are more likely to have or prefer to have more than one child. Specifically, among women who are not employed off the farm, 3.369 percent prefer no children and 33.157 percent prefer only one child. Thus, approximately 63 percent of women who are not employed prefer more than one child, and 56 percent of them have more than one child. In contrast, 
Table 1 Descriptive statistics

\begin{tabular}{|c|c|c|c|c|}
\hline \multirow{3}{*}{$\begin{array}{l}\text { Variables } \\
\text { Employment status² } \\
\text { Sample size }\end{array}$} & \multicolumn{4}{|c|}{ Mean $^{1}$} \\
\hline & \multicolumn{2}{|c|}{ Not employed } & \multicolumn{2}{|c|}{ Employed } \\
\hline & \multicolumn{2}{|c|}{$N=1514$} & \multicolumn{2}{|c|}{$\mathrm{N}=841$} \\
\hline \multicolumn{5}{|l|}{ Fertility variables } \\
\hline Preferred number of children & 1.768 & $(0.816)$ & 1.378 & $(0.695)$ \\
\hline Actual number of children & 1.650 & $(0.803)$ & 1.202 & $(0.632)$ \\
\hline \multicolumn{5}{|l|}{ Instrumental variables ${ }^{3}$} \\
\hline A bus stop in the village or neighborhood & 0.602 & & 0.747 & \\
\hline \multicolumn{5}{|l|}{ Other explanatory variables } \\
\hline Household annual income (RMB) & 18408.270 & $(26224.350)$ & 31250.620 & $(32105.140)$ \\
\hline Ethnic minority (wife and/or husband) & 0.156 & & 0.102 & \\
\hline Age & 40.546 & (7.679) & 38.960 & $(7.310)$ \\
\hline Married & 0.982 & & 0.967 & \\
\hline The first child is a son & 0.463 & & 0.477 & \\
\hline Wife has siblings & 0.967 & & 0.956 & \\
\hline Husband has siblings & 0.930 & & 0.888 & \\
\hline Smoking & 0.024 & & 0.004 & \\
\hline Drinking alcohol & 0.069 & & 0.124 & \\
\hline Health insurance & 0.452 & & 0.591 & \\
\hline \multicolumn{5}{|l|}{ Education } \\
\hline Less than primary school & 0.203 & & 0.050 & \\
\hline Primary school & 0.235 & & 0.096 & \\
\hline Lower middle school & 0.409 & & 0.380 & \\
\hline Upper middle school & 0.126 & & 0.168 & \\
\hline Technical school & 0.023 & & 0.164 & \\
\hline College & 0.003 & & 0.141 & \\
\hline \multicolumn{5}{|l|}{ Occupation } \\
\hline Worker & N/A & & 0.585 & \\
\hline Professional & N/A & & 0.166 & \\
\hline Manager & N/A & & 0.040 & \\
\hline Staff & N/A & & 0.130 & \\
\hline Other occupations & N/A & & 0.078 & \\
\hline \multicolumn{5}{|l|}{ Health status } \\
\hline Excellent & 0.119 & & 0.180 & \\
\hline Good & 0.542 & & 0.522 & \\
\hline Fair & 0.283 & & 0.282 & \\
\hline Poor & 0.057 & & 0.017 & \\
\hline Village or neighborhood population (in 1000) & 3.188 & $(4.106)$ & 5.540 & $(8.125)$ \\
\hline $\begin{array}{l}\text { Han nationality allowed to have two children } \\
\text { if the first child is female }\end{array}$ & 0.469 & & 0.233 & \\
\hline Receiving a subsidy if having one child & 0.668 & & 0.705 & \\
\hline Urban & 0.050 & & 0.439 & \\
\hline \multicolumn{5}{|l|}{ Province } \\
\hline Heilongjiang & 0.147 & & 0.112 & \\
\hline Liaoning & 0.116 & & 0.136 & \\
\hline
\end{tabular}


Table 1 Descriptive statistics (Continued)

\begin{tabular}{lll}
\hline Jiangsu & 0.075 & 0.149 \\
Shandong & 0.079 & 0.131 \\
Henan & 0.143 & 0.069 \\
Hubei & 0.104 & 0.102 \\
Hunan & 0.131 & 0.067 \\
Guangxi & 0.101 & 0.128 \\
Guizhou & 0.106 & 0.107 \\
\hline
\end{tabular}

Data source: China Health and Nutrition Survey 2006.

N/A not applicable.

${ }^{1}$ Standard deviations are reported in parentheses for continuous variables.

${ }^{2}$ Employment status is defined by whether an individual has a job off the farm.

${ }^{3}$ Instrumental variables are from China Health and Nutrition Survey Community Questionnaire 2006.

only about 34 percent of employed women prefer having more than one child, and just 23 percent of these women do have more than one child. We should stress that we expect preferred fertility to exceed actual fertility for at least two reasons: some women are young and still in their child-bearing years, and some may prefer more children than allowed.

\subsection{OLS and two-stage least squares estimation}

Table 3 presents the results using OLS estimation, thus not controlling for endogeneity. On average, female employment reduces the preferred number of children by 0.07 and the actual number of children by 0.12 . The coefficient on female employment status in the preferred fertility regression is statistically significant at the 10 percent level, and is

Table 2 Preferred and actual fertility in China, by woman's employment status, 2006

\begin{tabular}{|c|c|c|c|c|}
\hline \multirow{2}{*}{$\begin{array}{l}\text { Preferred number of } \\
\text { children }\end{array}$} & \multicolumn{2}{|c|}{ Not employed } & \multicolumn{2}{|c|}{ Employed } \\
\hline & Frequency & Percent & Frequency & Percent \\
\hline 0 & 51 & 3.369 & 31 & 3.686 \\
\hline 1 & 502 & 33.157 & 524 & 62.307 \\
\hline 2 & 756 & 49.934 & 230 & 27.348 \\
\hline 3 & 172 & 11.361 & 51 & 6.064 \\
\hline 4 & 20 & 1.321 & 4 & 0.476 \\
\hline 5 & 11 & 0.727 & 0 & 0.000 \\
\hline 6 & 2 & 0.132 & 1 & 0.119 \\
\hline Total & 1514 & 100.000 & 841 & 100.000 \\
\hline \multirow{2}{*}{ Actual number of children } & \multicolumn{2}{|c|}{ Not employed } & \multicolumn{2}{|c|}{ Employed } \\
\hline & Frequency & Percent & Frequency & Percent \\
\hline 0 & 67 & 4.425 & 57 & 6.778 \\
\hline 1 & 600 & 39.630 & 591 & 70.273 \\
\hline 2 & 678 & 44.782 & 165 & 19.620 \\
\hline 3 & 143 & 9.445 & 24 & 2.854 \\
\hline 4 & 17 & 1.123 & 3 & 0.357 \\
\hline 5 & 9 & 0.594 & 0 & 0.000 \\
\hline 6 & 0 & 0.000 & 1 & 0.119 \\
\hline Total & 1514 & 100.000 & 841 & 100.000 \\
\hline
\end{tabular}


Table 3 Ordinary least squares estimation of preferred and actual fertility

\begin{tabular}{|c|c|c|c|c|}
\hline \multirow[t]{2}{*}{ Variables } & \multicolumn{4}{|c|}{$\begin{array}{l}\text { Ordinary least squares estimation } \\
\text { (coefficient) }\end{array}$} \\
\hline & \multicolumn{2}{|c|}{$\begin{array}{l}\text { Preferred number } \\
\text { of children }\end{array}$} & \multicolumn{2}{|c|}{$\begin{array}{c}\text { Actual number } \\
\text { of children }\end{array}$} \\
\hline \multicolumn{5}{|l|}{ Not employed (reference) } \\
\hline Employed & -0.070 & $(0.042)^{*}$ & -0.120 & $(0.038)^{* * *}$ \\
\hline \multicolumn{5}{|l|}{ Other explanatory variables } \\
\hline Household annual income in natural log & 0.014 & $(0.008)^{*}$ & 0.011 & $(0.006)^{*}$ \\
\hline Ethnic minority (wife and/or husband) & 0.012 & $(0.053)$ & 0.050 & $(0.048)$ \\
\hline Age & -0.009 & $(0.020)$ & 0.084 & $(0.016)^{* * *}$ \\
\hline Age squared & 0.001 & $(0.001)$ & -0.001 & $(0.0002)^{* * *}$ \\
\hline Married & 0.087 & $(0.146)$ & 0.127 & $(0.129)$ \\
\hline The first child is a son & -0.117 & $(0.028)^{* * *}$ & -0.102 & $(0.026)^{* * *}$ \\
\hline Wife has siblings & 0.048 & $(0.077)$ & 0.035 & $(0.075)$ \\
\hline Husband has siblings & 0.056 & $(0.070)$ & 0.020 & $(0.063)$ \\
\hline Smoking & -0.089 & $(0.129)$ & -0.057 & $(0.125)$ \\
\hline Drinking alcohol & 0.088 & $(0.051)^{*}$ & 0.030 & $(0.046)$ \\
\hline Health insurance & 0.064 & $(0.033)^{* *}$ & 0.041 & $(0.031)$ \\
\hline \multicolumn{5}{|l|}{ Education } \\
\hline \multicolumn{5}{|l|}{ Less than primary school (reference) } \\
\hline Primary school & -0.140 & $(0.060)^{* *}$ & -0.138 & $(0.057)^{* *}$ \\
\hline Lower middle school & -0.220 & $(0.054)^{* * *}$ & -0.209 & $(0.051)^{* * *}$ \\
\hline Upper middle school & -0.330 & $(0.061)^{* * *}$ & -0.322 & $(0.058)^{* * *}$ \\
\hline Technologic school & -0.430 & $(0.078)^{* * *}$ & -0.352 & $(0.067)^{* * *}$ \\
\hline College & -0.344 & $(0.090)^{* * *}$ & -0.325 & $(0.074)^{* * *}$ \\
\hline \multicolumn{5}{|l|}{ Occupation } \\
\hline \multicolumn{5}{|l|}{ Worker (reference) } \\
\hline Professional & -0.058 & $(0.071)$ & -0.018 & $(0.058)$ \\
\hline Manager & -0.099 & $(0.101)$ & -0.044 & $(0.086)$ \\
\hline Staff & -0.031 & $(0.073)$ & 0.013 & $(0.058)$ \\
\hline Other occupations & -0.038 & $(0.087)$ & 0.007 & $(0.078)$ \\
\hline \multicolumn{5}{|l|}{ Health status } \\
\hline \multicolumn{5}{|l|}{ Excellent (reference) } \\
\hline Good & 0.020 & $(0.040)$ & -0.039 & $(0.037)$ \\
\hline Fair & 0.016 & $(0.048)$ & -0.053 & $(0.043)$ \\
\hline Poor & -0.029 & $(0.076)$ & -0.054 & $(0.076)$ \\
\hline \multicolumn{5}{|l|}{ Province } \\
\hline \multicolumn{5}{|l|}{ Heilongjiang (reference) } \\
\hline Liaoning & 0.140 & $(0.049)^{* * *}$ & 0.112 & $(0.044)^{* * *}$ \\
\hline Jiangsu & 0.028 & $(0.054)$ & 0.002 & $(0.049)$ \\
\hline Shandong & 0.127 & $(0.058)^{* *}$ & 0.044 & $(0.053)$ \\
\hline Henan & 0.553 & $(0.055)^{* * *}$ & 0.473 & $(0.051)^{* * *}$ \\
\hline Hubei & 0.290 & $(0.058)^{* * *}$ & 0.249 & $(0.051)^{* * *}$ \\
\hline Hunan & 0.391 & $(0.060)^{* * *}$ & 0.215 & $(0.051)^{* * *}$ \\
\hline
\end{tabular}


Table 3 Ordinary least squares estimation of preferred and actual fertility (Continued)

\begin{tabular}{lrrrr}
\hline Guangxi & 0.237 & $(0.078)^{* * *}$ & 0.195 & $(0.073)^{* * *}$ \\
Guizhou & 0.513 & $(0.070)^{* * *}$ & 0.451 & $(0.063)^{* * *}$ \\
Village or neighborhood population (in 1000) & -0.007 & $(0.003)^{* *}$ & -0.007 & $(0.002)^{* * *}$ \\
Han nationality allowed to have two childrenif the first child is female & 0.213 & $(0.037)^{* * *}$ & 0.260 & $(0.034)^{* * *}$ \\
Receiving a subsidy if having one child & -0.224 & $(0.040)^{* * *}$ & -0.167 & $(0.034)^{* * *}$ \\
Urban & -0.188 & $(0.052)^{* * *}$ & -0.223 & $(0.040)^{* * *}$ \\
Constant & 1.226 & $(0.436)^{* * *}$ & -0.906 & $(0.351)^{* * *}$ \\
Adjusted R squared & 0.240 & & 0.324 \\
\hline
\end{tabular}

Note: standard deviations are reported in parentheses.

* significant at the $10 \%$ level; ${ }^{* *}$ significant at the $5 \%$ level; *** significant at the $1 \%$ level.

significant at the 1 percent level for the actual fertility regression. These marginal effects of employment on fertility are somewhat smaller than those found in Table 1, possibly reflecting the endogeneity problems that the OLS approach encounters. Our results are consistent with the finding of Scotese and Wang (1995) that female employment significantly reduces fertility, although those authors do not control for the endogeneity of employment. The adjusted R squared of the OLS model is about 0.24 for the preferred fertility estimation and 0.32 for the actual fertility estimation.

Table 4 shows the results from the first-stage regressions predicting employment status (both OLS and probit) using our IV estimation approach. The instrumental variable (a bus stop in the community) proves to be positively and significantly related to female employment at the 1 percent level in both the OLS and probit estimations. Table 4 also reports various tests for the instrumental variable obtained from the two-stage least squares estimation using the preferred number of children as the dependent variable, including tests of excluded instruments, under-identification tests, and weak instrument-robust inference tests. Each of these tests is highly significant. For example, the F statistic of the weak identification test is 22.52, which is significant at the 1 percent level and indicates that the IV is not weak in the first stage estimation and affects employment status. The IV can be excluded from the fertility equation, meaning that availability of a bus stop does not affect fertility directly after controlling for female employment status. However, the endogeneity test by Wu-Hausman F statistic has a p value of 0.17 , even if our instrument for correcting endogeneity is valid. This insignificance may reflect that fertility measures are count variables and two-stage least squares estimation may not be appropriate.

Table 5 reports the second-stage estimation results by two-stage least squares after controlling for endogeneity. We find that the coefficients on female employment status remain negative, and are statistically significant. In addition, the absolute values of coefficients increase, suggesting that OLS estimation underestimates the negative effects of female employment on fertility.

\subsection{Poisson estimation}

Tables 6 and 7 show the estimated coefficients from the Poisson estimation. After correcting the endogeneity by the two-stage method in Table 7, the coefficient of female employment remains negative and statistically significant at the 5 percent level for the preferred fertility regression and at the 1 percent level for the actual fertility 
Table 4 The first stage estimation using the instrumental variable

\begin{tabular}{|c|c|c|c|c|}
\hline \multirow{3}{*}{$\begin{array}{l}\text { Estimation model } \\
\text { Instrumental variable }\end{array}$} & \multicolumn{4}{|c|}{$\begin{array}{l}\text { Estimation with "Employed" as } \\
\text { the dependent variable }\end{array}$} \\
\hline & \multicolumn{2}{|c|}{$\begin{array}{l}\text { Ordinary least } \\
\text { squares coefficient }\end{array}$} & \multicolumn{2}{|c|}{$\begin{array}{c}\text { Probit marginal } \\
\text { effect }\end{array}$} \\
\hline & & & & \\
\hline A bus stop in the village or neighborhood & 0.079 & $(0.017)^{* * *}$ & 0.106 & $(0.025)^{* * *}$ \\
\hline \multicolumn{5}{|l|}{ Other explanatory variables } \\
\hline Household annual income in natural log & 0.019 & $(0.004)^{* * *}$ & 0.041 & $(0.010)^{* * *}$ \\
\hline Ethnic minority (wife and/or husband) & -0.064 & $(0.024)^{* * *}$ & -0.100 & $(0.036)^{* * *}$ \\
\hline Age & 0.027 & $(0.009)^{* * *}$ & 0.055 & $(0.015)^{* * *}$ \\
\hline Age squared & -0.001 & $(0.001)^{* * *}$ & -0.001 & $(0.0002)^{* * *}$ \\
\hline Married & -0.025 & $(0.056)$ & -0.085 & $(0.102)$ \\
\hline The first child is a son & 0.007 & $(0.015)$ & 0.013 & $(0.023)$ \\
\hline Wife has siblings & -0.025 & $(0.0436)$ & -0.031 & $(0.072)$ \\
\hline Husband has siblings & -0.019 & $(0.035)$ & -0.001 & $(0.055)$ \\
\hline Smoking & -0.061 & $(0.037)^{*}$ & -0.197 & $(0.071)^{* *}$ \\
\hline Drinking alcohol & 0.024 & $(0.026)$ & 0.086 & $(0.044)^{* *}$ \\
\hline Health insurance & -0.014 & $(0.017)$ & 0.023 & $(0.026)$ \\
\hline \multicolumn{5}{|l|}{ Education } \\
\hline \multicolumn{5}{|l|}{ Less than primary school (reference) } \\
\hline Primary school & 0.026 & $(0.024)$ & 0.084 & $(0.048)^{* * *}$ \\
\hline Lower middle school & 0.122 & $(0.023)^{* * *}$ & 0.233 & $(0.041)^{* * *}$ \\
\hline Upper middle school & 0.136 & $(0.029)^{* * *}$ & 0.274 & $(0.051)^{* * *}$ \\
\hline Technologic school & 0.148 & $(0.039)^{* * *}$ & 0.512 & $(0.047)^{* * *}$ \\
\hline College & 0.109 & $(0.041)^{* * *}$ & 0.677 & $(0.023)^{* * *}$ \\
\hline \multicolumn{5}{|l|}{ Health status } \\
\hline \multicolumn{5}{|l|}{ Excellent (reference) } \\
\hline Good & -0.059 & $(0.023)^{* * *}$ & -0.082 & $(0.035)^{* * *}$ \\
\hline Fair & -0.046 & $(0.026)^{*}$ & -0.053 & $(0.037)$ \\
\hline Poor & -0.140 & $(0.039)^{* * *}$ & -0.214 & $(0.045)^{* * *}$ \\
\hline \multicolumn{5}{|l|}{ Province } \\
\hline \multicolumn{5}{|l|}{ Heilongjiang (reference) } \\
\hline Liaoning & 0.141 & $(0.028)^{* * *}$ & 0.259 & $(0.052)^{* * *}$ \\
\hline Jiangsu & 0.309 & $(0.033)^{* * *}$ & 0.444 & $(0.048)^{* * *}$ \\
\hline Shandong & 0.204 & $(0.030)^{* * *}$ & 0.354 & $(0.050)^{* * *}$ \\
\hline Henan & 0.019 & $(0.023)$ & 0.024 & $(0.050)$ \\
\hline Hubei & 0.152 & $(0.031)^{* * *}$ & 0.236 & $(0.057)^{* * *}$ \\
\hline Hunan & 0.032 & $(0.027)$ & 0.046 & $(0.054)$ \\
\hline Guangxi & 0.240 & $(0.035)^{* * *}$ & 0.420 & $(0.052)^{* * *}$ \\
\hline Guizhou & 0.160 & $(0.030)^{* * *}$ & 0.305 & $(0.057)^{* * *}$ \\
\hline Village or neighborhood population (in 1000) & -0.002 & $(0.001)^{* *}$ & -0.003 & $(0.002)$ \\
\hline $\begin{array}{l}\text { Han nationality allowed to have two children if the first } \\
\text { child is female }\end{array}$ & -0.033 & $(0.017)^{*}$ & -0.041 & $(0.027)$ \\
\hline Receiving a subsidy if having one child & 0.039 & $(0.019)^{* *}$ & 0.064 & $(0.030)^{* *}$ \\
\hline Urban & 0.306 & $(0.026)^{* * *}$ & 0.491 & $(0.032)^{* * *}$ \\
\hline Constant & -0.507 & $(0.196)^{* * *}$ & N/A & \\
\hline
\end{tabular}


Table 4 The first stage estimation using the instrumental variable (Continued)

\begin{tabular}{|c|c|c|c|}
\hline R squared & 0.378 & & $\mathrm{~N} / \mathrm{A}$ \\
\hline \multicolumn{4}{|l|}{ Tests of the first stage ${ }^{1}$} \\
\hline \multicolumn{4}{|l|}{ Test of excluded instruments } \\
\hline F statistic & 22.520 & $* * *$ & N/A \\
\hline \multicolumn{4}{|l|}{ Underidentification tests } \\
\hline Kleibergen-Paap rk LM statistic & 22.690 & $* * *$ & N/A \\
\hline Kleibergen-Paap rk Wald statistic & 22.960 & $* * *$ & N/A \\
\hline \multicolumn{4}{|l|}{ Weak identification test } \\
\hline Kleibergen-Paap Wald rk F statistic ${ }^{2}$ & 22.600 & * & N/A \\
\hline
\end{tabular}

regression, indicating that employment reduces fertility. The included residuals are also statistically significant.

The marginal effects by Poisson estimation are reported in Table 8. Without controlling for endogeneity, employment reduces the preferred number of children by 0.069 and reduces the actual number of children by 0.119 - marginal effects that are very close to those estimated by OLS (Table 3). After controlling for endogeneity with the two-stage residual inclusion Poisson estimation, the negative effects of employment on the preferred number of children and the actual number of children increase (in absolute value) to 0.352 and 0.498 , respectively. The marginal effects of Poisson estimation, after correcting for endogeneity, are smaller than those estimated by two-stage least squares in Table 4, probably reflecting the advantages of count variables estimation (since linear regressions may over-estimate the true effects).

Results using Poisson estimations are similar to those using OLS and two-stage least squares in terms of signs and magnitudes, and suggest that endogeneity leads to an underestimate of the negative effects of employment status on fertility. In addition, the included residual obtained from the first stage is positive and significant, confirming that the employment measure is potentially endogenous (Hausman 1978; Hausman 1983; and Wooldridge 2002), and the disturbance terms of the fertility Equation (1) and the employment Equation (2) are positively correlated. This positive correlation leads OLS and simple Poisson regressions to underestimate the effect of employment on fertility. Ordered probit estimations (reflecting the possibility that fertility decisions may be ordered choices for a family) are very similar (available upon request from the authors).

Employing our preferred Poisson estimations with two-stage residual inclusion, we find that household annual income positively affects both preferred fertility and actual fertility. Age and age squared are good predictors for actual fertility, but not for preferred fertility. Having a first child who is a son significantly reduces both preferred and actual fertility, as expected given the Chinese emphasis on sons. We also find that married women with health insurance are more likely to prefer or have more children. This may reflect that their birth expenses or health-care costs for their children are covered by insurance, or possibly reflect other correlates of having health insurance (such as husband's occupation). We also find that education reduces fertility, perhaps reflecting the differential opportunity costs of having more children for women with greater education. Education is also 
Table 5 Two-stage least squares estimations

\begin{tabular}{|c|c|c|c|c|}
\hline \multirow[t]{2}{*}{ Variables } & \multicolumn{4}{|c|}{ Two-stage least squares estimation } \\
\hline & \multicolumn{2}{|c|}{$\begin{array}{l}\text { Preferred number } \\
\text { of children }\end{array}$} & \multicolumn{2}{|c|}{$\begin{array}{c}\text { Actual number of } \\
\text { children }\end{array}$} \\
\hline \multicolumn{5}{|l|}{ Not employed (reference) } \\
\hline Employed & -0.638 & $(0.437)$ & -0.640 & $(0.393)^{*}$ \\
\hline \multicolumn{5}{|l|}{ Other explanatory variables } \\
\hline Household annual income in natural log & 0.025 & $(0.013)^{* *}$ & 0.022 & $(0.010)^{* *}$ \\
\hline Ethnic minority (wife and/or husband) & -0.031 & $(0.058)$ & 0.010 & $(0.055)$ \\
\hline Age & 0.006 & $(0.023)$ & 0.097 & $(0.020)^{* * *}$ \\
\hline Age squared & 0.000 & $(0.0003)$ & -0.001 & $(0.0003)^{* * *}$ \\
\hline Married & 0.072 & $(0.145)$ & 0.112 & $(0.132)$ \\
\hline The first child is a son & -0.112 & $(0.029)^{* * *}$ & -0.098 & $(0.027)^{* * *}$ \\
\hline Wife has siblings & 0.035 & $(0.082)$ & 0.024 & $(0.077)$ \\
\hline Husband has siblings & 0.049 & $(0.070)$ & 0.013 & $(0.064)$ \\
\hline Smoking & -0.119 & $(0.130)$ & -0.084 & $(0.126)$ \\
\hline Drinking alcohol & 0.102 & $(0.053)^{*}$ & 0.043 & $(0.049)$ \\
\hline Health insurance & 0.061 & $(0.034)^{*}$ & 0.038 & $(0.032)$ \\
\hline \multicolumn{5}{|l|}{ Education } \\
\hline \multicolumn{5}{|l|}{ Less than primary school (reference) } \\
\hline Primary school & -0.124 & $(0.062)^{* *}$ & -0.123 & $(0.057)^{* *}$ \\
\hline Lower middle school & -0.147 & $(0.079)^{*}$ & -0.143 & $(0.067)^{* *}$ \\
\hline Upper middle school & -0.250 & $(0.089)^{* * *}$ & -0.248 & $(0.078)^{* * *}$ \\
\hline Technologic school & -0.345 & $(0.104)^{* * *}$ & -0.273 & $(0.088)^{* * *}$ \\
\hline College & -0.277 & $(0.105)^{* * *}$ & -0.263 & $(0.086)^{* * *}$ \\
\hline \multicolumn{5}{|l|}{ Occupation } \\
\hline \multicolumn{5}{|l|}{ Worker (reference) } \\
\hline Professional & 0.235 & $(0.238)$ & 0.250 & $(0.212)$ \\
\hline Manager & 0.199 & $(0.253)$ & 0.229 & $(0.226)$ \\
\hline Staff & 0.221 & $(0.209)$ & 0.244 & $(0.183)$ \\
\hline Other occupations & 0.312 & $(0.281)$ & 0.327 & $(0.253)$ \\
\hline \multicolumn{5}{|l|}{ Health status } \\
\hline \multicolumn{5}{|l|}{ Excellent (reference) } \\
\hline Good & -0.017 & $(0.049)$ & -0.073 & $(0.045)$ \\
\hline Fair & -0.012 & $(0.055)$ & -0.079 & $(0.048)^{*}$ \\
\hline Poor & -0.109 & $(0.103)$ & -0.127 & $(0.099)$ \\
\hline \multicolumn{5}{|l|}{ Province } \\
\hline \multicolumn{5}{|l|}{ Heilongjiang (reference) } \\
\hline Liaoning & 0.229 & $(0.082)^{* * *}$ & 0.193 & $(0.077)^{* * *}$ \\
\hline Jiangsu & 0.186 & $(0.133)$ & 0.148 & $(0.124)$ \\
\hline Shandong & 0.247 & $(0.109)^{* *}$ & 0.154 & $(0.100)$ \\
\hline Henan & 0.565 & $(0.056)^{* * *}$ & 0.484 & $(0.053)^{* * *}$ \\
\hline Hubei & 0.371 & $(0.086)^{* * *}$ & 0.324 & $(0.077)^{* * *}$ \\
\hline Hunan & 0.404 & $(0.063)^{* * *}$ & 0.227 & $(0.055)^{* * *}$ \\
\hline Guangxi & 0.364 & $(0.129)^{* * *}$ & 0.312 & $(0.120)^{* * *}$ \\
\hline Guizhou & 0.603 & $(0.095)^{* * *}$ & 0.534 & $(0.090)^{* * *}$ \\
\hline
\end{tabular}


Table 5 Two-stage least squares estimations (Continued)

\begin{tabular}{lrrrr}
\hline Village or neighborhood population (in 1000) & -0.007 & $(0.003)^{* *}$ & -0.007 & $(0.002)^{* * *}$ \\
Han nationality allowed to have two children if the first child is female & 0.187 & $(0.044)^{* * *}$ & 0.236 & $(0.039)^{* * *}$ \\
Receiving a subsidy if having one child & -0.209 & $(0.043)^{* * *}$ & -0.153 & $(0.037)^{* * *}$ \\
Urban & -0.010 & $(0.143)$ & -0.060 & $(0.129)$ \\
Constant & 0.990 & $(0.483)^{* *}$ & -1.122 & $(0.393)^{* * *}$ \\
\hline
\end{tabular}

Note: standard deviations are reported in parentheses.

${ }^{*}$ significant at the $10 \%$ level; ${ }^{* *}$ significant at the $5 \%$ level; ${ }^{* * *}$ significant at the $1 \%$ level.

positively correlated with the probability of being employed. We do not find that a woman's occupation significantly affects fertility after controlling for employment status. Poor health status, not surprisingly, is associated with having and preferring fewer children. We also find that there is substantial variation in fertility among the 9 provinces, holding other factors fixed. Women living in less economically-developed provinces (Guangxi and Guizhou) or in agriculture-intensive provinces (Henan, Hubei, and Hunan) have and prefer to have more children.

\subsection{Sensitivity analyses}

We conducted various sensitivity analyses to check the robustness of our results. In the first sensitivity analysis, we examine heterogeneity by separating mothers with grown-up children from those with young children. We divided the entire sample into two subsamples according to the age of their youngest child. (The dividing median age of children was 16.24, an age that supports our study assumptions since 16-year-olds qualify as adults in China). This partition lets us know whether employment status affects fertility choices differently for women with young children compared to those with grown children. We thought it unlikely that women with older children would be likely or able to have more children. The results show that a job (employed off the farm) significantly reduces actual fertility by 0.17 for those women with young children (i.e., their youngest child is less than 16.24 years old), but had no effect on actual fertility choices of mothers whose youngest child is already at least 16.24 years old. One potential explanation is that off-farm employment imposes a higher cost on women with young children, compared to women with older children. The effects of employment on the preferred number of children in these two groups are not statistically significant ( $p$ values $>0.10$ ). Due to limited space, these sensitivity results are omitted from the paper, but are available from the authors upon request.

In a second sensitivity analysis, we examined fertility as a binary phenomenon. The first category contained women with 0 or 1 child, thus in accord with the most stringent form of the one-child policy. The second category contained women with 2 or more children. We then examined the effects of employment on this binary variable, which essentially represents strict adherence to the one-child policy. Our results show that employment reduces the probability of falling into the second category (and violating the one-child policy) by $29 \%$ ( $\mathrm{p}$ value $<0.05$ ).

\section{Conclusion}

Our prime finding is that off-farm employment reduces fertility for Chinese women. Based on our Poisson estimation with two-stage residual inclusion, which controls for 
Table 6 Poisson estimation of preferred and actual fertility

\begin{tabular}{|c|c|c|c|c|}
\hline \multirow[t]{2}{*}{ Variables } & \multicolumn{4}{|c|}{ Poisson estimation (coefficient) } \\
\hline & \multicolumn{2}{|c|}{$\begin{array}{l}\text { Preferred number } \\
\text { of children }\end{array}$} & \multicolumn{2}{|c|}{$\begin{array}{c}\text { Actual number } \\
\text { of children }\end{array}$} \\
\hline \multicolumn{5}{|l|}{ Not employed (reference) } \\
\hline Employed & -0.044 & $(0.026)^{*}$ & -0.085 & $(0.026)^{* * *}$ \\
\hline \multicolumn{5}{|l|}{ Other explanatory variables } \\
\hline Household annual income in natural log & 0.008 & $(0.005)$ & 0.007 & $(0.004)^{*}$ \\
\hline Ethnic minority (wife and/or husband) & 0.004 & $(0.031)$ & 0.033 & $(0.031)$ \\
\hline Age & -0.004 & $(0.012)$ & 0.081 & $(0.012)^{* * *}$ \\
\hline Age squared & 0.001 & $(0.001)$ & -0.001 & $(0.0002)^{* * *}$ \\
\hline Married & 0.066 & $(0.101)$ & 0.088 & $(0.096)$ \\
\hline The first child is a son & -0.071 & $(0.017)^{* * *}$ & -0.067 & $(0.017)^{* * *}$ \\
\hline Wife has siblings & 0.041 & $(0.050)$ & 0.049 & $(0.053)$ \\
\hline Husband has siblings & 0.038 & $(0.046)$ & 0.020 & $(0.046)$ \\
\hline Smoking & -0.040 & $(0.082)$ & -0.019 & $(0.080)$ \\
\hline Drinking alcohol & 0.054 & $(0.030)^{*}$ & 0.018 & $(0.031)$ \\
\hline Health insurance & 0.043 & $(0.020)^{* *}$ & 0.032 & $(0.021)$ \\
\hline \multicolumn{5}{|l|}{ Education } \\
\hline \multicolumn{5}{|l|}{ Less than primary school (reference) } \\
\hline Primary school & -0.063 & $(0.031)^{* *}$ & -0.057 & $(0.031)^{*}$ \\
\hline Lower middle school & -0.108 & $(0.028)^{* * *}$ & -0.100 & $(0.028)^{* * *}$ \\
\hline Upper middle school & -0.177 & $(0.035)^{* * *}$ & -0.179 & $(0.035)^{* * *}$ \\
\hline Technologic school & -0.270 & $(0.052)^{* * * *}$ & -0.234 & $(0.049)^{* * *}$ \\
\hline College & -0.218 & $(0.063)^{* * *}$ & -0.237 & $(0.053)^{* * *}$ \\
\hline \multicolumn{5}{|l|}{ Occupation } \\
\hline \multicolumn{5}{|l|}{ Worker (reference) } \\
\hline Professional & -0.047 & $(0.053)$ & -0.011 & $(0.047)$ \\
\hline Manager & -0.070 & $(0.076)$ & -0.028 & $(0.067)$ \\
\hline Staff & -0.043 & $(0.057)$ & -0.026 & $(0.051)$ \\
\hline Other occupations & -0.023 & $(0.057)$ & 0.010 & $(0.057)$ \\
\hline \multicolumn{5}{|l|}{ Health status } \\
\hline \multicolumn{5}{|l|}{ Excellent (reference) } \\
\hline Good & 0.016 & $(0.025)$ & -0.020 & $(0.025)$ \\
\hline Fair & 0.014 & $(0.030)$ & -0.030 & $(0.029)$ \\
\hline Poor & -0.015 & $(0.046)$ & -0.037 & $(0.048)$ \\
\hline \multicolumn{5}{|l|}{ Province } \\
\hline \multicolumn{5}{|l|}{ Heilongjiang (reference) } \\
\hline Liaoning & 0.097 & $(0.034)^{* * *}$ & 0.077 & $(0.033)^{* *}$ \\
\hline Jiangsu & 0.022 & $(0.039)$ & -0.005 & $(0.038)$ \\
\hline Shandong & 0.096 & $(0.039)^{* * *}$ & 0.039 & $(0.039)$ \\
\hline Henan & 0.344 & $(0.033)^{* * *}$ & 0.314 & $(0.032)^{* * *}$ \\
\hline Hubei & 0.190 & $(0.037)^{* * *}$ & 0.167 & $(0.035)^{* * *}$ \\
\hline Hunan & 0.257 & $(0.036)^{* * *}$ & 0.156 & $(0.035)^{* * *}$ \\
\hline Guangxi & 0.179 & $(0.048)^{* * *}$ & 0.160 & $(0.049)^{* * *}$ \\
\hline Guizhou & 0.330 & $(0.041)^{* * *}$ & 0.311 & $(0.040)^{* * *}$ \\
\hline
\end{tabular}


Table 6 Poisson estimation of preferred and actual fertility (Continued)

\begin{tabular}{lrrrr}
\hline Village or neighborhood population (in 1000) & -0.006 & $(0.003)^{* * *}$ & -0.007 & $(0.002)^{* * *}$ \\
Han nationality allowed to have two children if the first child is female & 0.120 & $(0.021)^{* * *}$ & 0.161 & $(0.021)^{* * *}$ \\
Receiving a subsidy if having one child & -0.129 & $(0.023)^{* * *}$ & -0.103 & $(0.022)^{* * *}$ \\
Urban & -0.126 & $(0.036)^{* * *}$ & -0.163 & $(0.030)^{* * *}$ \\
Constant & 0.133 & $(0.277)$ & -1.803 & $(0.271)^{* * *}$
\end{tabular}

Note: standard deviations are reported in parentheses.

${ }^{*}$ significant at the $10 \%$ level; ${ }^{* *}$ significant at the $5 \%$ level; ${ }^{* *}$ significant at the $1 \%$ level.

Table 7 Poisson estimations with two-stage residual inclusion

\begin{tabular}{|c|c|c|c|c|}
\hline \multirow[t]{2}{*}{ Variables } & \multicolumn{4}{|c|}{$\begin{array}{l}\text { Poisson estimation with two-stage } \\
\text { residual inclusion (coefficient) }\end{array}$} \\
\hline & \multicolumn{2}{|c|}{$\begin{array}{l}\text { Preferred number } \\
\text { of children }\end{array}$} & \multicolumn{2}{|c|}{$\begin{array}{l}\text { Actual number } \\
\text { of children }\end{array}$} \\
\hline Female employment status & & & & \\
\hline \multicolumn{5}{|l|}{ Not employed (reference) } \\
\hline Employed & -0.230 & $(0.121)^{* *}$ & -0.367 & $(0.120)^{* * *}$ \\
\hline Residual from the first stage & 0.110 & $(0.068)^{*}$ & 0.167 & $(0.068)^{* *}$ \\
\hline \multicolumn{5}{|l|}{ Other explanatory variables } \\
\hline Household annual income in natural log & 0.013 & $(0.006)^{* *}$ & 0.013 & $(0.005)^{* * *}$ \\
\hline Ethnic minority (wife and/or husband) & -0.010 & $(0.033)$ & 0.010 & $(0.034)$ \\
\hline Age & 0.002 & $(0.013)$ & 0.089 & $(0.013)^{* * *}$ \\
\hline Age squared & 0.001 & $(0.001)$ & -0.001 & $(0.0002)^{* * *}$ \\
\hline Married & 0.059 & $(0.103)$ & 0.077 & $(0.099)$ \\
\hline The first child is a son & -0.069 & $(0.018)^{* * *}$ & -0.063 & $(0.017)^{* * *}$ \\
\hline Wife has siblings & 0.038 & $(0.051)$ & 0.043 & $(0.053)$ \\
\hline Husband has siblings & 0.038 & $(0.046)$ & 0.021 & $(0.046)$ \\
\hline Smoking & -0.053 & $(0.084)$ & -0.039 & $(0.084)$ \\
\hline Drinking alcohol & 0.062 & $(0.034)^{*}$ & 0.032 & $(0.032)$ \\
\hline Health insurance & 0.047 & $(0.021)^{* *}$ & 0.038 & $(0.021)^{*}$ \\
\hline \multicolumn{5}{|l|}{ Education } \\
\hline \multicolumn{5}{|l|}{ Less than primary school (reference) } \\
\hline Primary school & -0.056 & $(0.032)^{*}$ & -0.048 & $(0.032)$ \\
\hline Lower middle school & -0.081 & $(0.033)^{* *}$ & -0.059 & $(0.032)^{*}$ \\
\hline Upper middle school & -0.145 & $(0.041)^{* * *}$ & -0.131 & $(0.042)^{* * *}$ \\
\hline Technologic school & -0.201 & $(0.065)^{* * *}$ & -0.128 & $(0.061)^{* *}$ \\
\hline College & -0.130 & $(0.082)$ & -0.104 & $(0.076)$ \\
\hline \multicolumn{5}{|l|}{ Occupation } \\
\hline \multicolumn{5}{|l|}{ Worker (reference) } \\
\hline Professional & -0.045 & $(0.054)$ & -0.008 & $(0.049)$ \\
\hline Manager & -0.069 & $(0.077)$ & -0.027 & $(0.070)$ \\
\hline Staff & -0.043 & $(0.057)$ & -0.025 & $(0.051)$ \\
\hline Other occupations & -0.027 & $(0.059)$ & 0.006 & $(0.057)$ \\
\hline \multicolumn{5}{|l|}{ Health status } \\
\hline \multicolumn{5}{|l|}{ Excellent (reference) } \\
\hline Good & 0.004 & $(0.027)$ & -0.038 & $(0.028)$ \\
\hline
\end{tabular}


Table 7 Poisson estimations with two-stage residual inclusion (Continued)

\begin{tabular}{lrlll}
\hline Fair & 0.005 & $(0.029)$ & -0.043 & $(0.031)$ \\
Poor & $-0.044(0.053)$ & -0.080 & $(0.053)$ \\
Province & & & & \\
Heilongjiang (reference) & & & & \\
Liaoning & 0.128 & $(0.040)^{* * *}$ & 0.125 & $(0.039)^{* * *}$ \\
Jiangsu & 0.071 & $(0.051)$ & 0.069 & $(0.051)$ \\
Shandong & 0.139 & $(0.048)^{* * *}$ & 0.103 & $(0.047)^{* *}$ \\
Henan & 0.349 & $(0.033)^{* * *}$ & 0.320 & $(0.034)^{* * *}$ \\
Hubei & 0.211 & $(0.039)^{* * *}$ & 0.199 & $(0.037)^{* * *}$ \\
Hunan & 0.260 & $(0.035)^{* * *}$ & 0.160 & $(0.036)^{* * *}$ \\
Guangxi & 0.224 & $(0.058)^{* * *}$ & 0.227 & $(0.059)^{* * *}$ \\
Guizhou & 0.360 & $(0.046)^{* * *}$ & 0.356 & $(0.045)^{* * *}$ \\
Village or neighborhood population (in 1000) & -0.006 & $(0.003)^{* * *}$ & -0.007 & $(0.002)^{* * *}$ \\
Han nationality allowed to have two children if the first child is female & 0.112 & $(0.022)^{* * *}$ & 0.150 & $(0.024)^{* * *}$ \\
Receiving a subsidy if having one child & -0.125 & $(0.022)^{* * *}$ & -0.097 & $(0.024)^{* * *}$ \\
Urban & -0.051 & $(0.059)$ & -0.049 & $(0.056)$ \\
Constant & 0.032 & $(0.269)$ & -1.954 & $(0.274)^{* * *}$ \\
\hline
\end{tabular}

Note: standard deviations are reported in parentheses.

${ }^{*}$ significant at the $10 \%$ level; ${ }^{* *}$ significant at the $5 \%$ level; ${ }^{* *}$ significant at the $1 \%$ level.

endogeneity of employment status, and holding other factors at the mean for our sample, off-farm employment reduces the preferred number of children by 0.35 and the actual number of children by 0.50 .

Why does controlling for endogeneity yield a more powerful negative effect of employment on fertility? We conjecture that controlling for the endogeneity of employment removes the income and wealth effects that positively impact fertility in China, ${ }^{19}$ while female employment per se exerts negative substitution effects. High incomes and wealth also allow parents to pay the penalty fines in China if they violate the one-child policy ${ }^{20}$. Because collinearity precludes us from including both employment and income (for females) in the same regression, the coefficient of non-instrumented employment includes both effects, which push in opposite directions. Once we instrument for employment, the mitigating impact of female income disappears, revealing the negative effect of off-farm employment on fertility. In addition, the

Table 8 Marginal effects using Poisson estimations

\begin{tabular}{|c|c|c|c|c|}
\hline \multirow{3}{*}{$\begin{array}{l}\text { Variables } \\
\text { Estimation model }\end{array}$} & \multicolumn{4}{|c|}{ Marginal effect } \\
\hline & \multicolumn{2}{|c|}{ Preferred number of children } & \multicolumn{2}{|c|}{ Actual number of children } \\
\hline & \multicolumn{4}{|c|}{ Poisson estimation } \\
\hline \multicolumn{5}{|l|}{ Female employment status } \\
\hline \multicolumn{5}{|l|}{ Not employed (reference) } \\
\hline Employed & -0.069 & $(0.040)^{*}$ & -0.119 & $(0.036)^{* * *}$ \\
\hline Estimation model & \multicolumn{4}{|c|}{ Poisson estimation with two-stage residual inclusion } \\
\hline \multicolumn{5}{|l|}{ Female employment status } \\
\hline \multicolumn{5}{|l|}{ Not employed (reference) } \\
\hline Employed & -0.352 & $(0.165)^{* *}$ & -0.498 & $(0.145)^{* * *}$ \\
\hline Residual from the first stage & 0.174 & $(0.101)^{*}$ & 0.238 & $(0.091)^{* * *}$ \\
\hline
\end{tabular}

Note: standard deviations are reported in parentheses.

* significant at the $10 \%$ level; ** significant at the $5 \%$ level; ${ }^{* * *}$ significant at the $1 \%$ level. 
effects of fertility on employment may be small. Angrist and Evans (1998) find that Ordinary Least Squares (OLS) without controlling for endogeneity overestimates the effect of fertility on labor supply and conclude that fertility per se may have a smaller impact on female labor supply than one might expect. The reverse causality issue in our study may not be highly consequential, and omitted variable biases (such as those regarding female income and employment opportunity) may dominate the endogeneity of the employment measure.

These findings provide empirical evidence regarding the economic theory of fertility and female labor force participation. In addition, they have potentially important implications for employment and fertility policies in China. Given the Chinese government's ongoing desire to curb population growth, the finding that female off-farm employment reduces fertility has important implications. Encouraging greater rates of off-farm employment for women could substantially reduce fertility without requiring any of the punishments and penalties for childbearing that have earned China so much criticism. Further improvements in women's education would complement pro-employment policies by increasing the productivity of employment and multiplying its fertility-reducing effects.

In sum, our study indicates that off-farm employment for Chinese women curbs both preferred and actual fertility. Given that economic performance and population size are two critical concerns for China, it is vital that this negative link be recognized.

\section{Endnotes}

${ }^{1}$ In the Soares and Falcao (2008) model, increasing adult longevity heightens incentives to invest in human capital, leading to a shift toward women working outside the home and reductions in the gender wage gap. Others have suggested several phases of demographic transition, with fertility first increasing and then decreasing as economy-wide productivity grows (see Lehr 2009).

${ }^{2} \mathrm{Li}$ and Zhang (2007) provide evidence suggesting that low fertility contributed to China's rapid economic growth since the 1980s.

${ }^{3}$ Schultz and Zeng (1995) find that female schooling and availability of health and family planning services significantly and negatively affect fertility in rural China. Rosenzweig and Zhang (2009) find that the one-child policy lowered fertility and increased the average "quality" of children; but neither set of authors analyzes female employment behavior.

${ }^{4}$ The benefits for a couple with only one child have included health care, housing, cash, and food subsidies (McElory and Yang 2000). Punishments for the employees of state-owned enterprises and governments who violate the policy may involve loss of promotion opportunities or even jobs; others are subject to cash penalties ( $\mathrm{Li}$ and Zhang 2009). Unpermitted babies are often not able to register their residency, nor to obtain their identification card until these punishments are carried out. During a particularly zealous period of enforcement in the 1980s, some areas imposed even more draconian measures, such as forced abortions and sterilizations (Hardee-Cleaveland and Banister 1988). Recently, policies have been changed to allow a couple whose two members are only children to have a second child. (China Daily 2006).

${ }^{5}$ The sex ratio at birth (boy/girls) increased from 1.056 in 1982 to 1.153 in 2000. The unnatural excessively male sex ratio at birth raises many challenges for China's society and economy, and many policies have been designed to ameliorate it (Li 2007). However, the 
2010 census revealed that the problem remains acute: for every 100 newborn girls, there are 118 newborn boys in China (Peng 2011).

${ }^{6}$ For simplicity, we assume salary $s$ is the increment to household income that can be attained from the woman switching from work on the farm to off-farm employment, and that the $\mathrm{K}$ hours of off-farm employment cannot be combined with childcare in the same way that work on the farm can.

${ }^{7}$ Figure 1 also shows that the cut-off line between $n^{*}=1$ and $n^{*}=2$ becomes steeper when women have better off-farm employment opportunities (access to a bus stop). Those with the highest salary offers were already employed, but now save time in commuting to work, and a few of them therefore switch to preferring a second child. Thus, even in this simple model of time trade-offs, there are forces pushing in opposite directions, and the impact of employment on fertility is an empirical question.

${ }^{8}$ This number equals the total number of children that a woman gives birth to, minus the number of children who have died, if any. If the woman is currently pregnant, this future birth is also counted as part of the cumulative fertility measure, because the current infant mortality rate in China is very low. Most women in China become pregnant soon after their marriage.

${ }^{9}$ Hesketh et al. (2005) find that 87 percent of married women in China use contraception, and 25 percent of reproductive-age women have at least one abortion.

${ }^{10}$ For example, using longitudinal surveys in Anhui and Guangdong provinces, Li et al. (2010) find that daughters' ability to support their parents has increased, particularly through off-farm labor including temporary migration to urban areas.

${ }^{11}$ In formulating the fertility preference question as it did, it seems clear that the CHNS surveyors felt that the chances of women preferring to have fewer children were remote.

${ }^{12}$ See Table 1.

${ }^{13} \mathrm{We}$ recognize that if there were a combination of three conditions - shocks to fertility across communities unrelated to employment, fertility significantly affected female employment, and female employment significantly influenced whether a bus stop would be installed - our instrument would measure fertility directly, not merely employment opportunities. This confluence of required conditions strikes us as unlikely. Moreover, if female employment did boost bus stops, the posited instrumental variable relationship would be overstated. This in turn would reduce the absolute impact of using instrumental variables compared to single-stage estimation, contrary to what we find. As reported below, the IV estimates magnify the negative effect of employment on fertility. Thus, if anything, this negative effect is underestimated in OLS, implying the hypothetical scenario outlined in this paragraph does not apply.

${ }^{14}$ Using the lagged instrument of bus stop availability may avoid the potential issue of female employment affecting the setup of a bus stop in the same year. The results using lagged bus stop existence are omitted due space limitations, but are available from the authors upon request.

${ }^{15} \mathrm{As}$ an additional robustness check, we replaced total household income with household income excluding any female income in the multivariate regressions; the results were very similar to those reported in the text.

${ }^{16}$ The marriage law in China sets a minimum legal age for women of 20 years. 
${ }^{17}$ For example, Yao (1999) reports the female employment rate in a rural county of Zhejiang province to be about 33 percent.

${ }^{18}$ Although fertility is higher in rural than urban areas, China's average total fertility per woman has remained under 2 since 1992 (McElroy and Yang 2000).

${ }^{19}$ Note that our estimate of a positive effect of income on fertility is consistent with the conceptual model but contrasts with Schultz and Zeng (1995) and most data for higher income countries.

${ }^{20}$ As most jobs in China are no longer in state-owned enterprises or government agencies, administrative tools are less effective, making penalty fines more powerful (McElroy and Yang 2000).

\section{Competing interests}

The IZA Journal of Labor \& Development is committed to the IZA Guiding Principles of Research Integrity. The authors declare that they have observed these principles.

\section{Acknowledgements}

The authors are grateful to a reviewer for extremely helpful comments and to Laurence Tai for excellent research assistance.

Responsible editor: Hartmut Lehmann

\section{Author details}

${ }^{1}$ China Center for Health Development Studies, Health Science Center, Peking University, No.38 Xueyuan Road, Haidian District, P.O. Box 505, Beijing 100191, China. Walter H. Shorenstein Asia-Pacific Research Center, Stanford University, Stanford, USA. ${ }^{3}$ Department of Economics and Department of Preventive Medicine, State University of New York at Stony Brook, Stony Brook, USA. ${ }^{4}$ John F. Kennedy School of Government, Harvard University, and National Bureau of Economic Research, Cambridge, USA.

Received: 22 July 2013 Accepted: 11 November 2013

Published: 09 Dec 2013

References

Angrist JD, Evans WN (1998) Children and their parents' labor supply: evidence from xxogenous variation in family size. Am Econ Rev 88(3):450-477

Banister J (1987) China's changing population. Stanford University Press, Redwood City, CA, USA

Becker GS (1960) An economic analysis of fertility. In: Becker GS (ed) Demographic and economic change in developed countries. Princeton University Press, Princeton, NJ, pp 209-231

Becker GS (1965) A theory of the allocation of time. Econ J 75(299):493-517

Bolumar F, Olsen J, Boldsen J (1996) Smoking reduces fecundity: a European multicenter study on infertility and subfecundity. Am J Epidemiol 143(6):578-587

Brown JC, Guinnane TW (2002) Fertility transition in a rural, catholic population: Bavaria, 1880-1910. Popul Studies 56(1):35-49

China Daily (2006) One child parents urged to have two kids. November 10, 2006., http://www.china.org.cn/english/ China/188489.htm

Coale AJ, Banister J (1996) Five decades of missing females in China. Proc Am Philos Soc 140(4):421-450

Crafts NFR (1989) Duration of marriage, fertility and women's employment opportunities in England and Wales in 1911. Popul Studies 43(2):325-335

Gourieroux CS, Monfort A, Renault E, Trognon A (1987) Generalised residuals. J Econom 34(1-2):5-32

Guinnane TW (2011) The historical fertility transition: a guide for economists. J Econ Lit 49(3):589-614

Hardee-Cleaveland K, Banister J (1988) Fertility policy and implementation in China, 1986-1988. Popul Dev Rev 14(2):245-286

Hausman JA (1978) Specification tests in econometrics. Econometrica 46(6):1251-1271

Hausman JA (1983) Specification and estimation of simultaneous equation models. In: Zvi G, Intriligator MD (eds) Handbook of Econometrics, vol 1. North-Holland, Amsterdam, pp 391-448

Hesketh T, Lu L, Xing Z (2005) The effect of China's one-child family policy after 25 years. N Engl J Med 353(11):1171-1176

Howe G, Westhoff C, Vessey M, Yeates D (1985) Effects of age, cigarette smoking, and other factors on fertility: findings in a large prospective Study. BMJ 290(6483):1697-1700

Hussain A (1994) Social security in present-day China and its reform. Am Econ Rev 84(2):276-280

Imbens G, Angrist J (1994) Identification and estimation of local average treatment effects. Econometrica 62(2):467-475

Kalwij AS (2000) The effects of female employment status on the presence and number of children. J Popul Econ 13(2):221-239

Killingsworth MR, Heckman JJ (1986) Female labor supply: a survey. In: Ashenfelter OC, Layard R (eds) The handbook of labor economics. North-Holland, Amsterdam, pp 103-204

Lehr CS (2009) Evidence on the demographic transition. Rev Econ Stat 91(4):871-887

Li H, Zhang J (2007) Do high birth rates hamper economic growth? Rev Econ Stat 89(1):110-117

Li H, Zhang J (2009) Testing the external effect of household behavior: the case of the demand for children. J Hum Resour 44(4):890-915 
Li S (2007) Imbalanced sex ratio at birth and comprehensive intervention in China., Available at http:/www.unfpa.org/ gender/docs/studies/china.pdf [accessed 1 November 2011]

Li S, Feldman MW, Jin X, Zuo D (2010) Gender, migration, and well-being of the elderly in rural China. Economic and Social Implications of Rapid Demographic Change in China, Japan, and South Korea, Stanford University Walter H. Shorenstein Asia-Pacific Research Center series with Brookings Institution Press, In Aging Asia

McElroy M, Yang D (2000) Carrots and sticks: fertility effects of China's population policies. Am Econ Rev 90(2):389-392

Mincer J (1962) Labor force participation of married women: a study of labor supply, Aspects of Labor Economics. National Bureau of Economic Research, Princeton University Press, Princeton, New Jersey, pp 63-97

Peng X (2011) China's demographic history and future challenges. Science 333(6042):581-587

Rivers D, Vuong OH (1988) Limited information estimators and exogeneity tests for simultaneous probit models. J Econom 39(3):347-366

Rosenzweig MR, Zhang J (2009) Do population control policies induce more human capital investment? Twins, birth weight and China's "one-child" policy. Rev Econ Stud 76(3):1149-1174

Schultz TP (1985) Changing world prices, women's wages, and the fertility transition: Sweden, 1860-1910. J Polit Econ 93(6):1126-1154

Schultz TP (1988) The relationship between local family planning expenditures and fertility in Thailand, 1976-1981. Yale University, Economic Growth Center

Schultz TP, Zeng Y (1995) Fertility of rural China. effects of local family planning and health programs. J Popul Econ 8(4):329-350

Scotese CA, Wang P (1995) Can government enforcement permanently alter fertility? the case of China. Econ Inq 33(4):552-570

Smith RJ, Blundell RW (1986) An exogeneity test for a simultaneous equation Tobit model with an application to labor supply. Econometrica 54(3):679-685

Soares RR, Falcao BL (2008) The demographic transition and the sexual division of labor. J Polit Econ 116(6):1058-1104

Terza JV, Basu A, Rathouz PJ (2008) Two-stage residual inclusion estimation: addressing endogeneity in health econometric modeling. J Health Econ 27(3):531-543

Wang F (2011) The future of a demographic overachiever: long-term implications of the demographic transition in China. Popul Dev Rev 37(s1):173-190

Willis RJ (1973) A new approach to the economic theory of fertility behavior. J Polit Econ 81(2):14-64

Wooldridge JM (2002) Econometric Analysis of Cross Section and Panel Data. MIT Press, the first edition, Cambridge, MA

Yao Y (1999) Rural industry and labor market integration in eastern China. J Dev Econ 59(2):463-496

Zhang J (1990) Socioeconomic determinants of fertility in China: a microeconometric analysis. J Popul Econ $3(2): 105-123$

10.1186/2193-9020-2-12

Cite this article as: Fang et al: Jobs and kids: female employment and fertility in China. IZA Journal of Labor \& Development 2013, 2:12

\section{Submit your manuscript to a SpringerOpen ${ }^{\circ}$ journal and benefit from:}

- Convenient online submission

- Rigorous peer review

- Immediate publication on acceptance

- Open access: articles freely available online

- High visibility within the field

- Retaining the copyright to your article

Submit your next manuscript at $\boldsymbol{\sim}$ springeropen.com 